\section{EIS 10/2016}

Dilemmas of Post-Enlargement Europe: Building an 'Insecurity Zone'?

Submitted 03/2016

Accepted for publication 09/2016

\section{Abstract}

\section{Introduction}

\section{ktu}

European Integration Studies No. $10 / 2016$

pp. 8-15

DOI 10.5755/j01.eis.0.10.14579 (c) Kaunas University of Technology
Dilemmas of

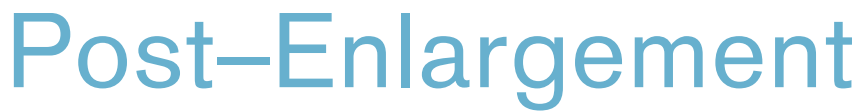

Europe: Building an

"Insecurity Zone"?

\section{Martin Dangerfield}

Department of History, Politics and War Studies, University of Wolverhampton

Wulfruna Street, Wolverhampton, WV1 1LY, United Kingdom

Гrossef http://dx.doi.org/10.5755/j01.eis.0.10.14579

This article reflects on the development and operation of the European Neighbourhood Policy (ENP) from the perspective of the post-1989 attempt to extend the West European 'Security Community' into the wider Europe via processes of both EU enlargement and attempts to foster deep integration with former Soviet states. Whilst the EU's strategy towards eastern neighbours should certainly not be taken as the sole or even key cause of the 'insecurity zone' in and around the EU's eastern frontier, it seems hard to avoid the conclusion that actions such as the ENP and EaP have played an important part in these developments. This is an analytical contribution rather than a study based on primary research. As well as extending existing discussions about the expansion of the European Security Community and the application of the 'Optimum Integration Area' concept to the EaP countries, the article includes a focus on EU states' economic relations with Russia which is a critical albeit underexplored constraint upon EU 'eastern' policy.

KEYWORDS: EU-Russia relations; Ukrainian crisis; Eastern Partnership; EU enlargement; EU trade with Russia.

2014 marked the ten year anniversary of the launch of the European Neighbourhood Policy (ENP) and the five year anniversary of its 'offspring' the Eastern Partnership (EaP). The war in Georgia in 2008, the present conflict in Ukraine with the ensuing annexation of Crimea and breakdown of relations with Russia were not expected to be its key results as far as the eastern sphere of the ENP was concerned. As Speck (2015), quoting the Economist, noted, "(i)nstead of having built a 'ring of friends,' the EU is now surrounded by a 'ring of fire'". Post-2004 attempts to develop close integration with selected post-Soviet countries have certainly not achieved the hoped-for spread of the 'European Security Community' further east. Whilst the EU's strategy towards eastern neighbours should certainly not be seen as the sole or even key cause of the 'insecurity zone' in and around the EU's eastern frontier, it seems hard to avoid the conclusion that actions such as the ENP and EaP have played an important part in these developments.

This article reflects on the development and operation of the ENP and EaP from the perspective of the post-1989 attempt to extend the West European 'Security Community' into the Wider Europe via processes of both EU enlargement and attempts to foster deep integration with former 
Soviet states. The article identifies some key contradictions of the EU's engagement with the eastern neighbourhood including the effects of important inconsistencies in policies towards the EaP countries on the one hand and towards Russia on the other. For the latter, this will include the implications of the relatively unnoticed but extremely important intensive economic interdependence that developed over the last decade or so due to the rapid growth of EU exports to the Russian market.

First, some definitions and a qualification. Post-enlargement Europe refers to Europe after the 2004 and 2007 EU enlargements and signifies that we are now in the era where big-bang expansions of the EU are over and the contours of the European project are more or less known, assuming the Western Balkans eventually gain accession (see Webber and Stivachtis, 2011). A security community is (Cottey 2007, 3) "a region where war between constituent states is highly improbable and virtually unthinkable. Disputes are resolved via cooperation in framework of common institutions". After 1945 a potent security community emerged in Western Europe in the framework of the process of European integration in the Cold War context. This therefore developed as the Deutschian pluralistic variant of security community where sovereignty remains primarily at state level though diluted through elements of supranational governance. The qualification is to stress that this article is concerned with the soft power based security role of the EU and the interplay between integration processes and security-building. EU enlargement to Central and Eastern Europe (CEE) was of course accompanied by the hard power based NATO expansion into the region as a broader and more explicit component of CEE security policy. Apart from the fact that NATO membership is more to do with perceived external conventional security threats and a comparison that can be drawn between the respective external and internal security roles of NATO and the European integration in post-war Western Europe, the ENP/EaP has not in any case been accompanied by NATO expansion to the EU's eastern neighbours.

After 1989 the West European security community began the process of spreading eastward and the security-building properties of the EU enlargement process became fully apparent during this time. For CEE each step forward in European integration was underpinned by conditionality that created the internal conditions for eventual membership of the EU and also of the extended European security community. The core conditions, otherwise known as the Copenhagen Criteria, included: transition to a market economy able to be competitive in the EU single market; resolution of local conflicts/tensions; democracy; and rule of law. Cottey (2007) wrote that "the western European security community that emerged during the cold war has outlasted the historical circumstances that gave rise to it, and is now the defining feature of the new security landscape. The emergence and consolidation of this security community has dramatically reduced the likelihood of war in Europe and in doing so fundamentally transformed the nature of security in Europe...the Western security community has also been a significant stabilising influence in central and eastern Europe, providing a powerful impetus for reform and moderation in the region. In the context of democratisation and integration with western institutions, central and eastern European states have made significant efforts to overcome historic disputes and develop new co-operative relationships (both bilaterally and multilaterally)".

The successful spread of the European Security Community to CEE is the main reason why the EU enlargement process has been hailed as the EU's most successful foreign policy ever. Nowadays, in 2016, the sustainability of this achievement is however under some question, with notions of 'disappearing democracy' and 'democratic backsliding' in new EU member states, especially Hungary and, more latterly Poland, having gained traction (Meuller 2014, Sedelmeier 2014, Inotai 2015). Even before these setbacks, the gloss of the 2004/2007 enlargement had also

\section{Security and Integration in Europe}


worn off somewhat with anti-free movement of people rhetoric having been growing steadily in several 'old' member states, most notably in the UK where immigration was a key issue in the June 2016 vote to leave the EU. Nevertheless it is only where the possible alternative scenarios for Europe, exemplified by the horrors of the former Yugoslavia in the 1990s, have been forgotten that doubts about the enormously positive impact of the EU's eastward expansion could seriously be harboured. Either way, the post-enlargement success is certainly not being replicated in the EU's engagement with the eastern neighbours. The manifold shortcomings of the ENP itself have been discussed at length by many scholars and will not be rehearsed here. Instead, the rest of the article focuses on some key reasons why the spread of the European security community into the ex-USSR was always bound to be a formidable, if not impossible task, regardless of how well the ENP may have been designed and why even a strategy based enlargement proper and not just enlargement 'lite' may well also have run aground.

Differentiated 'Zones' of Postcommunist/ Postenlargement Europe

The EU's differentiated approach to post-communist Europe became apparent almost immediately after the end of the Cold War. By 1993 it was clear that the countries comprising CEE were the most privileged group and set apart from the other post-communist countries, with membership on the horizon and association agreements in place or under negotiation. Europe. Relations with ex-Soviet countries, except for the Baltic States, were to be on the basis of Partnership and Association, which included neither membership nor deep integration perspectives. The countries of the conflict-ridden former Yugoslavia were by and large not engaged (with the exception of Macedonia) at all. By the end of the 1990s these enduring distinctions in patterns of EU engagement were reflected in how Europe was seen from the perspective of security. Hyde-Price (2002) identified three differentiated zones: core, intermediate and outer. The core zone, Western Europe, was of course itself a stable order and established security community. The states comprising the intermediate zone - CEE - (essentially those destined to be the 2004/2007 EU entrants) were so far less stable than the core zone but essentially peaceful because of the so-called 'triple transformation' from authoritarianism to democracy, from planned economy to market system and from belonging to the Council for Mutual Assistance (CMEA) to accession to the EU. The outer zone - the West Balkans and former USSR - was clearly going to be an increasingly difficult and challenging task as far as further spread of the European security community was concerned. This set of countries represented the least stable and most unpredictable zone characterized by slower domestic reform, post-conflict or frozen conflict contexts and lagging progress and/or uncertain prospects for Euro-Atlantic integration. This at least was the picture in the early 2000s when 'intermediate' zone states were on the cusp of EU accession.

As far as post-enlargement Europe is concerned, the basic pattern has continued. The modes of engagement with the Western Balkans and ex-Soviet states have undergone major change but the main three-way differentiation set in train in the early 1990s has been consolidated (see Dangerfield 2007) with varied statuses as far as the European security community is concerned. The first group is CEE, consisting of the eight May 2004 entrants plus (in spite of later entry and some variation in entry conditions) Bulgaria and Romania. These new EU members are now largely absorbed into the European security community. The second group consists of the West Balkan states all of whom have a membership promise (already honoured in the case of Croatia) and are en route to the EU, albeit with differentiated rates of progress. This region is also a site also of active EU peacekeeping and other Common Security and Defence Policy (CSDP) missions, reflecting the complex mix of security problems within that region. The third group includes East European states engaged in the ENP and since 2009, the EaP. These states are still denied a membership promise but have progressed to an association perspective. They have been subject 
to an EU vision or, some would say, rhetoric, in which they can develop a relationship short of full membership but nevertheless entailing advanced integration with the EU. This group is characterised by specific security complications and reform issues connected to the Soviet legacy and close relations with Russia. Russia itself has, of course, gone into a category of its own, especially since 2004 when it declined to participate in ENP. This marked the point in which EU and Russian competition for influence in the 'shared neighbourhood' began to crystallise (see below).

Each of the above-mentioned zones or 'concentric circles' has represented a progressively more complex and more challenging arena for the EU, yet the premise has been that the same method - enlargement or 'enlargement-lite' - can work in all these different settings. The fact that the EaP zone is now one of instability and crisis, at least for Ukraine, has not only finally confirmed the invalidity of that assumption, but has fuelled perspectives that the ENP/EaP strategy has actually undermined security in Europe by acting as a catalyst for struggle between reform and anti-reform elements in EaP countries that escalates into violent confrontation. Speck (2015), for example, argues, that while European integration should be of long term benefit - economic and political success - it can have de-stabilising effects in the short term. This is due to corrupt and self-serving elites that embrace cooperation with the EU to get benefits but resist full-blown transformation to liberal democracy and market economy. Europeanisation threatens them because it would empower the wider population and, inter alia, undermine 'cronyism' in the form of patronage and rent-seeking privileges. As Speck $(2015,2)$ writes, "it was not by accident that the EU's flag was waving over the maidan and that the refusal of the Association Agreement with the EU was what triggered the fall of the old Yanukovich regime". Thus Europeanisation processes seem to run up against deep-seated resistance to reform processes needed to forge a path to genuine integration with the EU. When, as in the Ukraine case, this results in violent clashes between elites and reformers the EU finds itself in the position of having been complicit in the outbreak of conflict but at the same time itself lacking the capacity to intervene, especially when Russia becomes involved as a key external actor. This is not, course to say, that the EU has no means of responding, as the subsequent economic sanctions on Russia, along with the subsequent offer of an Association Agreement for Ukraine and EU 'context' of the German and French role in achieving the 2015 Minsk Agreement show. Nevertheless, the EU itself has neither the political capacity nor the 'hard power' instruments in which to respond or intervene directly in such conflict situations and is always restricted to its usual post-conflict reconstruction and peace-building role, with even the diplomacy carried out during the conflict phase being carried out by the member states rather than the EU per se.

The third reason focuses on the use of the enlargement method even for countries without any formal prospect of joining the EU. The consequences of the lack of membership offer is well-worn argument which stresses that the absence of accession process undermines incentives to reform. Less noticed is incorrect sequencing of integration process with EU. According to the 'classical' method of EU enlargement (see Preston 1997) the first step is a 'classical free trade agreement' that involves basic tariff and quota removal. This is usually accompanied by insistence that the countries taking this initial step towards integration with the EU should also liberalise trade with each other, for example as per the Central European Free Trade Agreement (CEFTA). In the neighbourhood, the EU reversed the order and offered deep integration at the outset that entailed a massive, complex and long term regulatory alignment. Classical free trade arrangements of Europe Agreement type were a more appropriate first stage. These is because they were more feasible to introduce, and would have

\section{Unintended consequences of Europeanisa- tion - De- stabilisation?}

\section{Contradictory Application of the Enlargement Method}


acted as stepping-stones towards and a learning process for deeper integration. Moreover, they could have encouraged more foreign direct investment, especially if accompanied by regional free trade agreement or enabling the other EaP countries to follow the example of Moldova which is a member of CEFTA. The concept of Optimum Integration Area (OIA) developed by Dangerfield (2011) not only shows whether states are fit for membership at a specific time but also clearly suggests that the traditional sequencing of steps towards EU integration would have been more suitable for the EaP countries. To give a brief explanation of the OIA first, it adapts the 'Optimum Currency Area' (OCA) concept, which identifies necessary conditions for a viable currency union, to the EU enlargement issue. The OCA approach stresses that economic profiles of prospective participants must be sufficiently converged, otherwise unsuitable partners will put intolerable strains on the whole system. Following the same principle, the OIA uses a number of indicators to determine whether potential members could be absorbed without compromising the integration project. Dangerfield's model, which focused on the so-called Western Newly Independent States (WNIS) took into account GDP per capita, freedom and human rights, quality of economic and business governance according to World Bank governance indicators and progress in post-communist economic transition as measured by the European Bank for Reconstruction and Development (EBRD). It clearly showed that even at the time of launch of the EaP, let alone the ENP, the WNIS at least were not in a fit state for deep integration with EU.

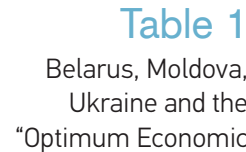

Area"

\begin{tabular}{l|c|c|c|c}
\hline & $\begin{array}{c}\text { Income per head } \\
2008(\$)\end{array}$ & $\begin{array}{c}\text { Freedom index } \\
2010(\mathrm{pr} / \mathrm{cl})\end{array}$ & $\begin{array}{c}\text { Quality of economic } \\
\text { regulation }\end{array}$ & $\begin{array}{c}2008 \text { transition } \\
\text { rating (EBRD) }\end{array}$ \\
\hline EU25 & 28497 & $1 / 1$ & 1.38 & - \\
\hline Iceland & 36299 & $1 / 1$ & 1.12 & $\mathrm{~N} / \mathrm{a}$ \\
\hline Norway & 49072 & $1 / 1$ & 1.34 & $\mathrm{~N} / \mathrm{a}$ \\
\hline Switz. & 38031 & $1 / 1$ & 1.66 & $\mathrm{~N} / \mathrm{a}$ \\
\hline Ukraine (47.1 million) & 6750 & $3 / 2$ (free) & -0.39 & 3.07 \\
\hline Moldova (4.2 million) & 2738 & $3 / 4$ (partly free) & -0.20 & 3.0 \\
\hline Belarus (9.8 million) & 11329 & $7 / 6$ (not free) & -1.24 & 2.04 \\
\hline Romania & 11704 & $2 / 2$ & 0.53 & 3.44 \\
\hline Bulgaria & 11239 & $2 / 2$ & 0.75 & 3.56 \\
\hline
\end{tabular}

Source: Dangerfield (2011)

Contradictions between Neighbourhood Policy and the Strategy towards Russia
The final argument rests on the assumption that relations between the $\mathrm{EU}$ and $\mathrm{EaP}$ countries are a sub-system of EU-Russia relations. One perspective on this is the Mearsheimer (revived) thesis that the EU has been complicit (with NATO) in creating a new grave security crisis in in the post Cold-War 'multipolar' Europe. This is through disregard for Russia's perceived interests and pushing Euro-Atlantic structures to Russia's front door. Again, this paper stresses a different contradiction and one that has played an important role in hampering EU support for EaP countries and undermines the ability of the EU to deal with the de-stabilising consequences of Europeanisation as noted above.

The basic point to be stressed here is that the EU has promoted and supported Europeanisation in the 'shared' neighbourhood whilst simultaneously building strong economic interdependence 
with Russia. EU companies have massively expanded exports to Russia since around 2000 and particularly after 2005. This of course was on the back of Russia's oil-fired import boom: between 2005 and 2010 imports doubled from US \$bn 79.7 to 197.5 US \$bn (Dangerfield 2015). The relationship with Russia is obviously crucial to successful engagement with eastern neighbours, yet a ten year process of building economic interdependence with Russia means that trade considerations are at the heart of the difficulty of achieving a unified EU stance when it comes to economic statecraft towards Russia. Criticism of sanctions and some 'behind the scenes' business as usual in some aspects of bilateral ties (see Dangerfield 2015) are evidence of this. For example it was interesting to note that many leading not only US but also European multinational companies attended the annual 'St Petersburg International Economic Forum in late June 2015. This was in marked contrast to 2014 when most stayed away. The decision of some member states (such as Hungary and Slovakia) to reconvene meetings of bilateral intergovernmental trade and economy commissions after having suspended them in 2014, is a further evidence that the complex web of EU-Russia trade and economic ties is well beyond the comprehensive control of the EU and that a multilateral approach to economic ties with Russia has clear parameters.

To further illustrate this issue, we can point out that the new EU members states have also been significant participants in the overall EU export boom to Russia. Taking the three 'small' Visegrad states as an example, Viktor Orban and Robert Fico have been openly critical of EU sanctions on Russia and there have similar interventions by Czech President Milos Zeman. Rather than some kind of sudden political lurch towards Russia, this represents economic pragmatism based on the rather dramatic increase in the significance of the Russian market over the last decade or so. Table 2 demonstrates the extent to which the Czech Republic, Hungary and Slovakia have all expanded exports to Russia since EU accession and also shows how this was set in the overall EU boom. Energy dependence is another important consideration for the three. The gas trade is well publicized, the nuclear energy issue less so. Table 3 shows the importance of nuclear energy for the three. Russia is the key partner in this sector (Dangerfield 2015).

\begin{tabular}{l|c|c|c|c|c|c|c}
\hline & 2004 & 2006 & 2008 & 2010 & 2012 & 2013 & $\begin{array}{c}\text { INDEX } \\
2013 / 2004\end{array}$ \\
\hline Czech Exports & 770 & 1504 & 2911 & 2672 & 4760 & 4474 & 581 \\
\hline Hung. Exports & 738 & 1617 & 2666 & 2583 & 2567 & 2538 & 344 \\
\hline Slovak Exports & 271 & 549 & 1811 & 1933 & 2638 & 2457 & 906 \\
\hline EU 27 Exports & 46123 & 72400 & 104970 & 86308 & 123442 & 119780 & 260 \\
\hline
\end{tabular}

Source: Dangerfield (2015)

\begin{tabular}{l|c|c} 
& $\begin{array}{c}\text { No. of Soviet-built } \\
\text { reactors }\end{array}$ & $\begin{array}{c}\text { Nuclear power as \% of domestic elec- } \\
\text { tricity generation }\end{array}$ \\
\hline Czech Republic & 6 & $33 \%$ \\
\hline Hungary & 4 & $33 \%$ \\
\hline Slovakia & 4 & $55 \%$ \\
\hline
\end{tabular}

Source: Dangerfield (2015)
Table 2

Czech, Hungarian and Slovak exports to Russia 2004-2013 (Euro, millions)

\section{Table 3}

Nuclear energy capacity in the Czech Republic, Hungary and Slovakia 

pean security community. This has been based primarily on the internal transformations of CEE post-communist states and their absorption into the EU (alongside NATO expansion). Also, despite the ongoing challenges in the Western Balkans and inevitable longer term membership perspectives of many states in that region, no one could deny the role that European integration has played in pacifying and stabilising the former Yugoslavia. Whatever the eventual outcomes within the West Balkans, the contours of post-enlargement Europe suggest that the final limits of EU expansion are now known. This also means that the spread of the European security community may have also run aground, at least for the foreseeable future. There can be no doubt that at the present time the EU's eastern neighbourhood looks more like an 'insecurity zone' plagued by open or frozen conflict.

- Does the failure to achieve successful spread of the European security community reflect the failure of EU policies or intractable complications of the eastern neighbourhood itself, including but not wholly down to, the Russia factor? Much more research will be needed on that key question in the future, but either way the Ukraine crisis and all its ramifications confirmed a widespread acceptance that the fundamental re-assessment of the ENP that took place during 2015 was long overdue. The European Commission's November 2015 review of ENP stresses that differentiation and greater mutual ownership will be its hallmarks from now on (European Commission, 2015). The new approach appears to be more pragmatic and less based on the enlargement model than its predecessor but whether it will provide a more effective framework for EU engagement with its neighbours remains to be seen.

\section{References}

BBC News (2015) 'Ukraine ceasefire: New Minsk agreement key points', 12 February. Retrieved 15 June, 2015 from http://www.bbc.co.uk/news/ world-europe-31436513

Cottey, A. (2007) Security in the New Europe. London: Palgrave.

Dangerfield, M. (2015) 'Economic Relations Between Visegrad Group Countries and Russia: How Much Has Changed?' paper presented at the EUSA Fourteenth Biennial Conference, March 5-7, Boston Massachusetts.

Dangerfield, M (2011) 'Belarus, Moldova and Ukraine: In or Out of European Regional International Society, Journal of European Integration, (Special Issue: 'Europe after Enlargement', edited by M. Webber and I Stivachtis), 33(2), 215-233

Dangerfield, M (2007) 'The European Union And Post-Communist Europe: One Approach Or Several?', Communist Studies and Transition Politics, 23, (4), 478-500 http://dx.doi. org/10.1080/13523270701674566

European Commission (2015) 'Joint Communication To The European Parliament, The Council, The European Economic And Social Committee And The Committee Of The Regions', Brussels. 18.11.15, JOIN(2015) 50 final.
Hyde-Price, A. (2002) 'European Security in the Twenty-First Century: Towards a Stable Peace Order?' in A. Cottey and D. Averre (eds.) New Security Challenges in Post-communist Europe (pp.190-212). Manchester: Manchester University Press: Manchester

Hungarian Government, (2015) 'We have strengthened our cooperation with Russia', 17 February. Retrieved 4 November, 2015 from www.kormany.hu/en/the-prime-minister/news/ we-have-strengthened-our-cooperation-withrussia

A. Inotai (2015) 'Hungary on the Way from a Liberal to Illiberal System. Introductory Remarks', Südost-Europa, 63(2), 167-172

J-W Meuller, (2014) 'Eastern Europe Goes South. Disappearing Democracy in the EU's Newest Members' Foreign Affairs, March/April, 2014, 14-19.

Prague Post (2015) 'Czech-Russian Plan Catches Babiš Unawares', 28 January. Retrieved 2 March 2015 from www.praguepost.com/czechnews/44035-czech-russian-plan-catches-babis-unawares

Preston, C. (1997) Enlargement and Integration in the European Union. London: Routledge. 
http://dx.doi.org/10.4324/9780203195871

U. Speck (2015) 'EU faces tough choices in the neighbourhood', euobserver.com, 20 May. Retrieved 15 June, 2015 from https://euobserver. com/opinion/128728

J. Mearsheimer (2014) 'Why the Ukraine Crisis is the West's fault. The Liberal Delusions that Provoked Putin' Foreign Affairs, September/October, 77-89.

U. Sedelmeier (2014) 'Anchoring Democracy from Above? The European Union and Demo- cratic Backsliding in Hungary and Romania after Accession', Journal of Common Market Studies, 52(1), 105-121. http://dx.doi.org/10.1111/ jcms. 12082

Spief16 News, (2015) 'Ministry of Industry and Trade promotes cooperation between Russia and Slovakia in high-technology industries', 6 May. Retrieved 19 November, 2015 from https:// forumspb.com/en/2015/sections/22/materials/196/news/307

\section{MARTIN DANGERFIELD}

BA (Hons), M.Sc., PhD, Jean Monnet Chair in the European Integration of East and Central Europe

\section{About the author}

Department of History, Politics and War Studies University of

Wolverhampton

\section{Fields of research interests}

EU-Russia Relations, European Neighbourhood Policy, EU Enlargement, Visegrad Cooperation

\section{Address}

Wulfruna Street, Wolverhampton, WV1 1LY, United Kingdom

E-mail: M.Dangerfield@wlv.ac.uk 